To cite: A Rudman 'Women's access to regional justice as a fundamental element of the rule of law: The effect of the absence of a women's rights committee on the enforcement of the African Women's Protocol' (2018) 18 African Human Rights Law Journal 319-345

http://dx.doi.org/10.17159/1996-2096/2018/v18n1a15

\title{
Women's access to regional justice as a fundamental element of the rule of law: The effect of the absence of a women's rights committee on the enforcement of the African Women's Protocol
}

\author{
Annika Rudman* \\ Professor of International Law, Department of Public Law, University of \\ Stellenbosch, South Africa
}

\section{Summary}

As stipulated by the CEDAW Committee, the right of access to justice for women is a fundamental element of the rule of law, which is essential to the realisation of women's human rights everywhere. As also pointed out by the CEDAW Committee, one important aspect of women's access to justice is the implementation of international instruments and decisions in international and regional justice systems related to women's rights. In line with this focus, the CEDAW Committee urges states to establish credible monitoring mechanisms for the implementation of international law. This article discusses one such mechanism or, rather, the absence of such a mechanism, namely, the lack of a specialised committee on the rights of women in Africa under the African Women's Protocol. The article provides an analysis of the effects of the absence of a committee on the rights of women in Africa on the monitoring and enforcement of women's rights relating to the border issue of access to justice. This analysis refers to three inter-linked lines of inquiry. The first is whether the structure and procedure established by the African Women's and African Court Protocols are obstructing women's human rights claims from reaching the Court. The second line of inquiry relates to whether the use of preconceived, mainstream mechanisms to monitor women's rights is conducive to promoting and protecting women's rights and, lastly, whether the limited

* LLM (Lund) PhD (Gothenburg); arudman@sun.ac.za 
jurisprudence on women's rights that have been produced by the African Commission supports or rejects the idea that the Commission is conscious of its women's rights mandate.

Key words: African Women's Protocol; gender equality; rule of law; women's access to justice

\section{Introduction}

The rule of law, as a primary principle underlying the African Union $(A U)$, is set to guide all its functions and processes. However, the rule of law, understood as the observance of good laws, containing within it the core values of human rights, is not a complete remedy for the compounded problems of the women of this continent. As highlighted by Mutua, '[g]ender remains among the thorniest challenges to the rule of law' $^{2}{ }^{2}$ In line with Mutua's argument, situating gender at the heart of the rule of law debate, this core concept needs to be informed and, arguably, transformed by feminist theories of subordination and intersectionality. ${ }^{3}$

The centrality of gender to the concept of the rule of law is recognised in the Declaration of the High-Level Meeting of the General Assembly on the Rule of Law at the National and International Levels, which emphasises the 'importance of establishing appropriate legal and legislative frameworks to prevent and address all forms of discrimination and violence against women and to secure their empowerment and full access to justice'. ${ }^{4}$ When a gender analysis is applied, to unearth the multifaceted ways in which women experience discrimination, exclusion and domination, one may be able to establish the limitations contained in the rule of law continuum and, consequently, better safeguard the lives, dignity and security of African women.

As stipulated by the Committee on the Convention on the Elimination of All Forms of Discrimination Against Women (CEDAW Committee), the right of access to justice for women is a fundamental element of the rule of law, and it is essential to the realisation of women's human rights everywhere. ${ }^{5}$ The right of access to justice is multidimensional. It encompasses 'justiciability, availability, accessibility, good quality and accountability of justice systems, and

1 Art 4(m) of the Constitutive Act of the African Union, adopted on 11 July 2000, entered into force 26 May 2001, OAU Doc CAB/LEG/23.15 (2001).

2 M Mutua 'Africa and the rule of law' (2016) 23 SUR International Journal on Human Rights 169.

3 As above.

4 UNGA 'Declaration of the high-level meeting of the General Assembly on the rule of law at the national and international levels' 30 November 2012, UN Doc A/ $\mathrm{RES} / 67 / 1$ para 16.

5 UN Committee for the Elimination of All Forms of Discrimination against Women 'General Recommendation 33 on women's access to justice' CEDAW/C/GC/33 3. 
provision of remedies for victims' ${ }^{6}$ As pointed out by the CEDAW Committee, one important aspect of women's access to justice is the implementation of international instruments and decisions in international and regional justice systems related to women's rights. In line with this focus, the CEDAW Committee urges states, individually or through international or regional co-operation, to establish credible monitoring mechanisms for the implementation of international law. ${ }^{7}$ This article discusses one such mechanism or, rather, the absence of such a mechanism, namely, the lack of a specialised committee on the rights of women in Africa under the Protocol to the African Charter on Human and Peoples' Rights on the Rights of Women in Africa (African Women's Protocol). The article departs from two main assumptions: first, that using the mainstream human rights institutions (and not a specialised committee on the rights of women in Africa) would present several challenges in the implementation of women's rights; second, that a specialised women's rights institution would serve two important purposes, namely, as a receiver of litigation and as a driver of implementation, with the potential of increasing women's access to justice and providing important insights into the African Women's Protocol.

The discussion in the article is mindful of the fact that access to regional and international human rights institutions usually is beyond the reach of millions of African women suffering from discrimination, violence and oppression. As international human rights litigation is built upon the principle of state sovereignty and, thus, around the principle of exhaustion of local remedies, limitations to access on the domestic level generally prevent access at the regional level. Access to resources, knowledge, legal aid and proficient legal representation are other major hurdles to women's access to justice domestically and regionally. However, the objective of the article is not to address these aspects of women's access to justice in the 55 states making up the AU. The aim rather is to emphasise how access to regional justice, through institutional structures, such as the African Commission on Human and Peoples' Rights (African Commission) and the African Court on Human and Peoples' Rights (African Court), could be improved to support the domestic implementation and enforcement of the African Women's Protocol and, as such, the rule of law.

In the following sub-sections, the analysis of the lack of a committee on the rights of women in Africa under the African Women's Protocol and its effects on the monitoring and enforcement of women's rights refers to three inter-linked lines of inquiry. The first is whether the structure and procedure established by the African Women's and African Court Protocols are obstructing women's human rights claims from reaching the Court. The second line of inquiry is whether the use of preconceived, mainstream mechanisms

6 General Recommendation 33 (n 5 above) para 14.

7 General Recommendation 33 para 56. 
to monitor women's rights is conducive to promoting and protecting women's rights; and, lastly, whether the limited jurisprudence on women's rights that have been produced by the African Commission supports or rejects the idea that the Commission is conscious of its women's rights mandate.

\section{Absence of a women's rights committee under the African Women's Protocol}

In January 2009, the AU Assembly of Heads of States declared 20102020 the African Women's Decade. Although it is evident that women's human rights feature prominently on the current AU agenda, specialised, operational women's rights institutions are incongruously missing from the regional institutional human rights framework. The African Women's Protocol was created to overcome a paradox, referred to by Viljoen as creating another legal instrument to overcome the deficiencies of the already-existing instrument, namely, the African Charter on Human and Peoples' Rights (African Charter) and the Convention on the Elimination of All Forms of Discrimination Against Women (CEDAW). ${ }^{8}$ The problem, however, as referred to by Banda, is not the normative deficiency of international or regional human rights law dealing with women's human rights, but rather the lack of implementation of such rights. ${ }^{9}$ Implementation primarily should be driven by a willingness of state parties to make good on its ratifications, through domestication and access to remedies in cases of non-compliance. However, as argued in this article, a focal point, a specialised women's rights institution, arguably would go a long way towards promoting implementation through both a specialised promotional and protective mandate.

For progressive women's rights treaties to be meaningful, the institutions established to interpret and enforce these treaties must assist in transforming such law into action through specialised promotional and protectional mandates. An important mechanism through which international human rights law becomes operative and accessible is through the interpretation and application of the law by judicial and quasi-judicial bodies. Recent studies reveal that decisions by such institutions can usher in a significant, domestic, human rights policy change, consequently supporting the rule of law. ${ }^{10}$ A good example is the CEDAW Committee's salient interpretation of the nondiscrimination clause in the CEDAW confirming, for example, that

8 F Viljoen International human rights law in Africa (2012) 251.

9 F Banda 'Blazing a trail: The African Protocol on Women's Rights comes into force' (2006) 50 Journal of African Law 74.

10 C Hillebrecht 'The power of human rights tribunals: Compliance with the European Court of Human Rights and domestic policy change' (2014) 20 European Journal of International Relations 1117. 
gender-based violence is a form of discrimination. ${ }^{11}$ The CEDAW Committee, in cases such as AT $v$ Hungary, later applied this interpretation. $^{12}$ This groundbreaking understanding of violence, as a form of discrimination, has reverberated in domestic jurisprudence across the globe, confirming the importance of the interpretation provided by this specialised women's human rights institution.

However, for treaty bodies to be able to interpret and apply women's human rights law, women must have reasonable access to these bodies. In contrast to the specific women's rights mandate of the CEDAW Committee or the child rights mandate of the African Committee of Experts on the Rights and Welfare of the Child (African Children's Committee), established under the African Charter on the Rights and Welfare of the Child (African Children's Charter), the African Women's Protocol contains no reference to a specialised monitoring body (referred to as a committee on the rights of women in Africa). Thus, no specialised women's rights institution exists on the African continent which is able to draw women's issues into what arguably is still a patriarchal system. Furthermore, there is no specialised institution to bring women's claims of human rights violations to the forefront. ${ }^{13}$ Instead, the African Women's Protocol relies on an existing, mainstream, human rights structure, created by the African Charter, namely, the African Commission and the African Court as founded by the Protocol to the African Charter on Human and Peoples' Rights on the Establishment of a Court on Human and Peoples' Rights (African Court Protocol). As suggested by Engle, human rights institutions entrusted with enforcing all human rights (such as the African Commission and African Court) must arrange or re-arrange its priorities in order to be able to protect specific women's rights. ${ }^{14}$ The question is whether such arrangements or rearrangements have been made and, furthermore, whether access to justice is hindered by the attitude towards women's rights displayed by, for example, the African Commission, as is further discussed in part 3.2 below.

While the ratification of the African Women's Protocol has been relatively successful, the invisibility of women's rights in the decisions and judgments of the treaty bodies set up to protect women's rights on the African continent is glaring. The African Women's Protocol to

11 UN Committee for the Elimination of All Forms of Discrimination against Women 'General Recommendation $19^{\prime}$ in 'Note by the Secretariat, Compilation of General Comments and General Recommendations Adopted by Human Rights Treaty Bodies' 29 July 1994, UN Doc HRI/GEN/1/Rev 1.

12 Communication 2/2003 UN Doc CEDAW/C/32/D/2/2003 (2005).

13 Viljoen (n 8 above) 249.

14 K Engle 'Female subjects of public international law: Human rights and the exotic other female' (1992) 26 New England Law Review 1516. 
date has been ratified by 39 of the $55 \mathrm{AU}$ member states. ${ }^{15}$ It has been in force for a period of ten years or longer in 24 of these states. However, as stated by Oré J, the current Judge-President of the African Court: ${ }^{16}$

[I]n spite of the massive ratification of the [African Women's Protocol] on the rights of women, expectations about the volume of litigation have been disappointing .... [t]his ... is disappointing in view of the serious violations experienced by African girls and women.

Oré $\mathrm{J}$ is pointing to an important issue. Almost 12 years after the African Women's Protocol came into force, there still has been no judgment by the African Court or decision by the African Commission specifically enforcing the rights set out in the African Women's Protocol. This is notwithstanding the fact that violations of women's human rights are rampant on the African continent. It is pertinent to ask why this is the case.

Currently there are less than a handful of cases pending before the African Court and African Commission with the potential of breaking this mould. For example, in June 2016, the Court received an application from Mariam Kouma directing a complaint to the African Court regarding violations of article 3(1) (dignity); article 3(4) (protection from violence); and article 8(a) (effective access to justice) of the African Women's Protocol. ${ }^{17}$ The Court heard this case on 16 May 2017. In September 2016, the Court furthermore received an application from the Association pour le Progrès et la Défense des Droits des Femmes and the Institute for Human Rights and Development in Africa against Mali, challenging the Malian Code of Persons providing for marriages to be concluded with persons under the age of $18 .^{18}$ This case specifically refers to article 2(2) (the obligation to modify harmful social and cultural practices); article 6(a) (full consent in marriage); article 6(b) (minimum age of marriage); and article 21 (the

15 Following the adoption of the Solemn Declaration on Gender Equality in Africa in July 2004, all member states of the AU undertook to (i) sign and ratify the African Women's Protocol by the end of 2004; (ii) support the launching of the public campaign aimed at ensuring its entry into force by 2005; and (iii) usher in an era of domestication and implementation of the African Women's Protocol, as well as other national, regional and international instruments on gender equality. In the AU Gender Policy, launched in 2009, member states furthermore undertook to achieve full ratification and enforcement of the African Women's Protocol by 2015 and its domestication by 2020 .

16 Final Communique of the 59th ordinary session of the African Commission on Human and Peoples' Rights, 21 October to 4 November 2016, Banjul, The Gambia, para 10.

17 Application 40/2016, Mariam Kouma v Republic of Mali (Kouma), African Court on Human and Peoples' Rights.

18 Application 46/2016, APDF and IHRDA v Republic of Mali (IHRDA), African Court on Human and Peoples' Rights. 
right to inheritance) of the African Women's Protocol. ${ }^{19}$ These are encouraging developments. However, the position remains that very little reference has been made directly to the African Women's Protocol which targets to address the marginalisation of women in Africa and to strengthen the rule of law. If this is not appropriately addressed, women's rights litigation will continue trickling instead of streaming in the regional domain.

\section{African Women's Protocol and its enforcement mechanisms}

The AU Assembly adopted the African Women's Protocol on 11 July 2003, and it entered into force on 25 November 2005, after the fifteenth ratification required had been made. It was established under article 66 of the African Charter, as a special protocol to supplement the provisions of the Charter. The CEDAW has been ratified by all AU member states except the Sharawi Arab Democratic Republic (which is not a member of the United Nations (UN)), Somalia and Sudan. Accordingly, there is a complete overlap between the state parties to the African Women's Protocol and the CEDAW. Out of the 39 member states of the AU that have ratified the African Women's Protocol, 37 states have been bound to the CEDAW for 20 years or longer. The exceptions are Mauritania and Swaziland, which ratified the CEDAW in 2001 and 2004 respectively. Conclusively, out of the 39 member states of the $\mathrm{AU}$ that have ratified the African Women's Protocol, all these states have been bound by the CEDAW for a period extending over ten years.

The African Women's Protocol arguably is a comprehensive treaty, prohibiting all forms of discrimination, harmful cultural practices and domestic violence against women and girls. It prescribes rights to property and inheritance and contains civil and political as well as socio-economic rights. As far as the latter category is concerned, the African Women's Protocol protects the general health of women and their reproductive health, and prescribes certain rights for women subjected to or living with HIV/AIDS. According to article 2 of the Women's Protocol, state parties furthermore have a comprehensive obligation to protect women from discrimination by state and nonstate actors.

19 In addition, there is an interesting case pending a decision of seizure by the African Commission concerning collective rape during military operations in the Democratic Republic of the Congo (DRC). Institute for Human Rights and Development in Africa (IHRDA) 'Case against the Democratic Republic of Congo before the African Commission, on collective rape during military operations' October 2016 http://www.ihrda.org/2016/10/case-against-the-democratic-repub lic-of-congo-before-the-african-commission-on-collective-rape-during-military-ope rations/ (accessed 8 February 2018). 
As alluded to above, unlike the African Children's Charter, the African Women's Protocol does not constitute a committee on the rights of women in Africa. Born out of the same Charter, the African Charter, and the idea that specific protection is required for certain vulnerable groups such as children, the African Children's Charter established the African Children's Committee in 1999. In comparison, the Children's Charter has been ratified by 48 states, and the African Children's Committee, which held its first meeting in 2002, is entrusted with the specific mandate to promote and protect the rights and welfare of the child. ${ }^{20}$ It consists of 11 impartial members with a specific competency in matters of the rights and welfare of children. ${ }^{21}$ The Children's Committee can receive communications from any person, group, non-governmental organisation (NGO), ${ }^{22}$ state party, or the UN relating to any matter covered by the African Children's Charter. ${ }^{23}$ It can furthermore investigate any matter falling within the ambit of the Children's Charter and receives periodic reports from member states. The African Children's Committee has thus far finalised four communications, 24 and three communications are currently pending before the Children's Committee. ${ }^{25}$ It has issued 31 Concluding Observations based on reports submitted by state parties. Of the 48 member states to the African Children's Charter, 33 states have submitted their initial reports, and seven have submitted periodic reports. The Children's Committee moreover to date has issued two General Comments as well as a joint General Comment with the African Commission. ${ }^{26}$

20 Arts 32 \& 42 African Children's Charter.

21 Art 33 African Children's Charter.

22 Recognised by the OAU, read AU.

23 Art 44(1) African Children's Charter.

24 Michelo Hansungule (on behalf of children in Northern Uganda) $v$ The Government of Uganda 001/Com/001/2005; Institute for Human Rights and Development in Africa (IHRDA) and Open Society Justice Initiative on behalf of children of Nubian descent in Kenya $v$ The Government of Kenya 002/Com/002/2009; The Centre for Human Rights (University of Pretoria); La Rencontre Africaine pour la Defense Des Droits de I'Homme (Senegal) v The Government of Senegal 003/Com/001/2012; and Minority Rights Group International and SOS-Esclaves on behalf of Said Ould Salem and Yarg Ould Salem v The Republic of Mauritania 007/Com/003/2015.

25 Institute for Human Rights and Development in Africa $v$ The Government of Malawi 004/Com/001/2014; African Centre of Justice and Peace Studies (ACJPS) and People's Legal Aid Centre (PLACE) $v$ the Government of Republic of Sudan 005/Com/001/ 2015; and The Institute for Human Rights and Development in Africa and Finders Group Initiative on behalf of TFA (a minor) $v$ The Government of Republic of Cameroon 006/Com/002/2015.

26 African Committee of Experts on the Rights and Welfare of the Child General Comment 1 (Article 30 of the African Charter on the Rights and Welfare of The Child) on 'Children of Incarcerated and Imprisoned Parents and Primary Caregivers' 8 November 2013; African Committee of Experts on the Rights and Welfare of the Child, General Comment 2 on article 6 of the African Charter on the Rights and Welfare of the Child: 'Right to Birth Registration, Name and Nationality' 16 April 2014; and Joint General Comment of the African Commission on Human and Peoples' Rights and the African Committee of Experts on the Rights and Welfare of the Child on Ending Child Marriage 30 January 2018. 


\subsection{Role of the Court in enforcing women's rights}

The African Women's Protocol relies on the existing human rights structure, as created by the African Charter and the African Court Protocol, to monitor the implementation of the rights set out therein. When the African Women's Protocol was negotiated, the Court Protocol had been conceived and adopted; however, the Court had not yet become operational. The African Women's Protocol prescribes that pending the establishment of the African Court, the African Commission has the responsibility to hear matters pertaining to the interpretation and application of the Women's Protocol. As will be further discussed below, the bulk of the protection mandate today still lies with the Commission, even though the African Court has been in operation since 2004.

The African Women's Protocol appoints the African Court as the primary institution that should be 'seized with matters of interpretation arising from the application or implementation of ... [the] Protocol'. ${ }^{27}$ This implies that if the rights are not implemented or the application of the rights of member states are not done in accordance with the African Women's Protocol, the African Court may hear such claims. Therefore, the Court would have jurisdiction under article 3 of the African Court Protocol vis-à-vis states that have ratified the Court Protocol as well as the African Women's Protocol, and it would equally be able to apply the provisions of the African Women's Protocol under article 7 of the Court Protocol. Of the 30 states $^{28}$ that have ratified the African Court Protocol, $25^{29}$ have also ratified the African Women's Protocol, substantiating the material jurisdiction of the Court. In this context, it is also important to note that the Court is able to hear women's rights cases based on articles 2, 3 and 18(3) of the African Charter, and the CEDAW where a state party has ratified the Court Protocol but not the African Women's Protocol. Of the five states $^{30}$ that have not ratified the African Women's Protocol, four ${ }^{31}$ have ratified the CEDAW. The African Court's material jurisdiction is determined by article 3 of the Court Protocol, as mentioned above, indicating that for the Court to have material jurisdiction over an international treaty it has to be relevant, of a human rights nature and ratified by the state in question.

27 Art 27 African Women's Protocol.

28 African Union Protocol to the African Charter on Human and Peoples' Rights on the Establishment of an African Court on Human and Peoples' Rights 1 April 2016 https://au.int/sites/default/files/treaties/7778-sl-protocol_to_the_african_charter on_human_and_peoplesrights_on_the_estab.pdf (accessed 12 February 2018).

30 Chad, Ethiopia, Niger, Sahrawi Arab Democratic Republic and Tunisia.

31 The Sharawi Arab Democratic Republic that has not ratified the CEDAW. 
Besides material jurisdiction, the African Court also has to assume personal jurisdiction to be able to hear a case. ${ }^{32}$ The Court Protocol stipulates that the African Commission; a state party that has lodged a complaint to the Commission; a state party against which the complaint has been lodged at the Commission; a state party of which the citizen is a victim of a human rights violation; and African intergovernmental organisations have locus standi before the African Court. ${ }^{33}$ Only in cases where the state has made a declaration under article 34(6) of the Court Protocol (an optional jurisdiction declaration), accepting the jurisdiction of the Court to hear complaints by individuals and NGOs (with observer status), may the Court accept such complaints. ${ }^{34}$ Currently seven states have made such declarations. ${ }^{35}$ All seven states furthermore have ratified the African Women's Protocol. ${ }^{36}$ Conclusively, only individual victims or NGOs (with observer status) in seven out of 55 African states can complain directly to the primary mechanisms stipulated in the African Women's Protocol, that is, the African Court, with regard to violations under the African Women's Protocol.

In the 22 states that have ratified both the African Court Protocol (without making an optional jurisdiction declaration) and the African Women's Protocol, a case concerning a violation of the African Women's Protocol can only reach the Court through (i) a referral by the African Commission; ${ }^{37}$ (ii) as a complaint submitted by an African intergovernmental organisation; ${ }^{38}$ (iii) as an inter-state complaint; ${ }^{39}$ or (iv) as a referral by the state that has been accused of human rights violations before the African Commission. ${ }^{40}$ Thus far, the Commission has referred three cases to the Court. ${ }^{41}$ Moreover, as the African Women's Protocol does not establish a committee on the rights of

32 See Application 004/2013 Lohe Issa Konate v Burkina Faso, African Court on Human and Peoples' Rights 5 December 2014 para 30. The Court has to establish four instances of jurisdiction, namely, ratione personae, materiae, temporis and loci.

33 Art 5 Court Protocol.

34 Arts 5(3) \& 34(6). See also App 001/2008 Michelot Yogogombaye $v$ Republic of Senegal, African Court on Human and Peoples' Rights 15 December 2009 para 37.

35 Burkina Faso, deposited 28 July 1998; Malawi, deposited 9 October 2008; Mali, deposited 19 February 2010; Tanzania, deposited 29 March 2010; Ghana, deposited 10 March 2011; Côte d'Ivoire, deposited 23 July 2013; and Benin, deposited 8 February 2016. Tunisia signed on 13 April 2017 but has not yet deposited its declaration. Rwanda deposited its declaration on 6 February 2013 and officially withdrew it on 24 February 2016.

36 See n 28 above.

37 Art 5(1)(a) African Court Protocol; Rule 118 Rules of Procedure of the African Commission on Human and Peoples' Rights.

38 Art 5(1)(e) African Court Protocol.

39 Arts 5(1)(b) \& (d).

40 Art 5(1)(c).

41 App 002/2013, The African Commission on Human and Peoples' Rights $v$ Libya, African Court on Human and Peoples' Rights 3 June 2016; App 004/2011 The African Commission on Human and Peoples' Rights $v$ Great Socialist People's Libyan Arab Jamahiriya, African Court on Human and Peoples' Rights (struck out) and App 006/2012, The African Commission on Human and Peoples' Rights $v$ Republic of Kenya, African Court on Human and Peoples' Rights 26 May 2017. 
women in Africa, and as the African Children's Committee does not constitute an African intergovernmental organisation according to the Court, $^{42}$ it is not clear what other AU/African body would have an interest and equally possess locus standi to submit such a claim. Furthermore, inter-state complaints are very rare, and it is unlikely that such a claim would involve women's rights. ${ }^{43}$ In the last scenario, where a state that has been cited as a respondent party before the African Commission, the complaint would voluntarily be subjected to the binding judgments of the African Court, and would in all likelihood involve the Court as an appeal body. Except for the Commission, as alluded to above, none of the other entities with locus standi before the Court has thus far lodged a complaint.

\subsection{Role of the African Commission in enforcing women's rights}

\subsubsection{State reports}

The African Commission has since 1987 been entrusted with monitoring state compliance with the African Charter. In addition, as discussed above, the Commission acts as a transitional monitoring body for the African Women's Protocol in relation to states that have ratified the Women's Protocol but that have not yet ratified the Court Protocol, and states that have ratified the African Women's Protocol and the Court Protocol but which have not yet made an optional jurisdiction declaration. Furthermore, article 60 of the African Charter stipulates that the African Commission 'shall draw inspiration' from human rights instruments adopted by the UN, as ratified by African states. The CEDAW falls under this category.

Under article 26 of the African Women's Protocol state parties undertake to submit periodic reports every two years, on the measures taken (both administrative and legislative) to implement their obligations, in accordance with article 62 of the African Charter and rule 73 of the Rules of Procedure of the African Commission. ${ }^{44}$ In order to assist member states in fulfilling their reporting obligations, the Commission has adopted Guidelines for State Reporting under the

42 African Court on Human and Peoples' Rights, Request for Advisory Opinion 002/ 2013 - The African Committee of Experts on the Rights and Welfare of the Child on the Standing of the African Committee of Experts on the Rights and Welfare of the Child before the African Court on Human and Peoples' Rights (ACRWC advisory opinion) para 93.

43 Democratic Republic of the Congo v Burundi, Rwanda and Uganda (2004) AHRLR 19 (ACHPR 2004).

44 As approved by the African Commission on Human and Peoples' Rights during its 47th ordinary session held in Banjul, The Gambia, 12-26 May 2010. 


\section{African Women's Protocol (Guidelines). ${ }^{45}$ These Guidelines stipu- late: ${ }^{46}$}

A state party to the African Charter and the Protocol must submit its report in two parts: Part A, dealing with the rights in the African Charter, and Part $B$, dealing with the rights in the Protocol. A state's first report under Part B must, preferably, not exceed 50 pages and subsequent reports should not exceed 30 pages.

Therefore, there is no separate reporting procedure for the African Women's Protocol. Instead, the African Commission relies on state parties to submit joint reports on the African Charter and the Women's Protocol for consideration. This reporting process is problematic, as the two reports are easily conflated. As an example, reports on the African Charter and the Women's Protocol are not listed separately on the Commission's homepage. Thus, there is no clear indication as to how many or which states have reported under the African Women's Protocol. It is sometimes difficult to distinguish between the two different reports and to find separate and relevant information on the status of state reporting under the African Women's Protocol.

As indicated above, of the 48 member states to the African Children's Charter, 33 states have submitted their initial reports, and seven have subsequently submitted periodic reports. Even considering the fact that the Children's Charter has been in force five years longer than the African Women's Protocol, the progress of state reporting under the Women's Protocol is substantially slower than under the Children's Charter. Currently, only seven out of the 39 state parties have submitted an initial report under the African Women's Protocol. ${ }^{47}$ Only Nigeria has repeatedly reported. As article 62 of the African Charter instructs states to report every two years, it is clear that the majority of state parties do not consider reporting under the African Women's Protocol a priority.

45 Guidelines for state reporting under the Protocol to the African Charter on Human and Peoples' Rights on the Rights of Women in Africa, adopted during the 46th ordinary session of the African Commission held from 11 to 25 November 2009 in Banjul, The Gambia. The 46th ordinary session was covered in the 27th Activity Report of The African Commission.

46 Guidelines (n 45 above) 1.

47 Mauritania's 10th, 11th, 12th, 13th and 14th Periodic Report 2006-2014 (not yet considered by the African Commission); Rwanda's 11 th, 12th and 13th Periodic Report 2009-2016 (not yet considered by the African Commission); South Africa's 2nd Periodic Report 2003-2014, considered at the 58th ordinary session of the African Commission, 6-20 April 2016, Banjul, The Gambia; Namibia's 6th Periodic Report 2011-2014, considered at the 58th ordinary session of the African Commission, 6-20 April 2016, Banjul, The Gambia; Burkina Faso's 3rd and 4th Periodic Report 2011-2015, considered at the 57th ordinary session of the African Commission, 4-18 November 2015, Banjul, The Gambia; Malawi's Initial and Combined Reports, 1995-2013, considered at the 56th ordinary session of the African Commission, 21 April-7 May 2015, Banjul, The Gambia; Nigeria's 5th Periodic Report 2011-2014, considered at the 56th ordinary session of the African Commission, 21 April-7 May 2015, Banjul, The Gambia; and Nigeria's 6th Periodic Report 2015-2016 (not yet considered by the African Commission). 


\subsubsection{Individual complaints}

As of November 2015, the African Commission had received 581 communications. Of these, 408 communications had been finalised and three ${ }^{48}$ transferred to the African Court. ${ }^{49}$ It is notable that out of more than 400 finalised communications, the Commission has engaged with women-specific issues in only ten communications dating back to 1996, as part of broader claims of human rights violations.

It is evident that the Commission cannot choose the cases it eventually considers. The individual complaints process as set out in the African Charter, mainly in articles 45, 55, 56 and 59, is initiated by the complainant. There are undoubtedly several external reasons why women's claims do not, in general, reach the Commission (and for that matter the Court), thus hampering women's access to justice. These include the slow implementation of certain provisions of the African Women's Protocol; the lack of state reporting under article 26 of the African Women's Protocol and the conflation of state reports (as discussed above under 3.2.1); the persistent challenges to the universality of women's human rights vis-à-vis moral or traditional African values and how these relate to the different roles of women; the use of religion and culture to defend harmful and violent practices; a lack of awareness of human rights instruments in general and, more specifically, the African Women's Protocol; and a lack of progress regarding women's rights due to state-specific conditions and events such as environmental challenges, conflicts and health epidemics. ${ }^{50}$ However, a lack of engagement with women's issues at the African Commission cannot only be explained by these external factors. Currently there are 514 NGOs with observer status listed with the Commission. ${ }^{51}$ Of these, at least 50 NGOs specifically list women's rights as part of their mandate. ${ }^{52}$ In this regard, it is

48 See n 41 above.

49 Inter-Session Activity Report of the Working Group on Communications May 2015-October 2015), presented to the 57th ordinary session of the African Commission on Human and Peoples' Rights, Banjul, The Gambia, 4-18 November 20154 para 16.

50 African Union Special Rapporteur on the Rights of Women in Africa and UN Office of the High Commissioner for Human Rights 'Report on women right's in Africa' 52 http://reliefweb.int/sites/reliefweb.int/files/resources/WomensRightsinAfrica_ singlepages.pdf (accessed 12 February 2018).

51 Resolution 33 on the Criteria for Granting and Enjoying Observer Status to NonGovernmental Organisations Working in the Field of Human and Peoples' Rights, 5 May 1999, adopted at the 25th ordinary session of the African Commission held in Bujumbura, Burundi, 26 April-5 May 1999. The 25th ordinary session is covered in the 12th Activity Report of the African Commission, Assembly of Heads of State and Government 35th ordinary session, 12-14 July 1999, Algiers, Algeria, AHG/ 215 (XXXV).

52 African Commission on Human and Peoples' Rights 'NGOs with observer status' 2018 http://www.achpr.org/network/ngo/by-name/ (accessed 12 February 2018). 
important to note that NGOs often 'contribute to the development of international law through litigation'.53 However, judging from the existing jurisprudence, this is not the case with regard to women's rights. One of the main reasons, as is further argued below, is that the Commission has not contributed to a culture where women's claims are prioritised. By not engaging with, detailing and personifying women's human rights claims, the Commission has not appropriately acted on its mandate to protect all human rights. Thus, individuals and NGOs seemingly are not prone to approach the Commission on these issues. Thus far the Commission has not decided any communication based on the African Women's Protocol. In a few cases, as discussed below, the Commission furthermore has failed to apply the CEDAW where applicable. In six cases, the Commission has been confronted with violations of women's rights in terms of rape and sexual violence during conflict. In another three cases, women's rights have been considered in relation to human dignity (article 5 of the African Charter) during detention, in relation to corporal punishment and immigration policies. ${ }^{54}$ Only one case before the Commission refers specifically to women's rights (gender-based violence and sexual violence) and discrimination against women under articles 2, 3 and 18(3) of the African Charter. ${ }^{55}$ The following sub-sections detail how the Commission's priorities and perceptions of women's rights have been entrenched, but also developed, in its jurisprudence from 1996 to 2013.

\section{African Commission's 'women as victims of rape' discourse}

The rape of girls and women has featured, as a violation of human rights, before the African Commission in cases from 1999 to 2009, that is, over a period of 10 years. ${ }^{56}$ These cases relate to situations of civil or border-crossing wars, either during hostilities or in the

53 R Murray The African Commission on Human and People's Rights and international law (2000) 95.

54 Organisation Mondiale Contre la Torture \& Others $v$ Rwanda (2000) AHRLR 282 (ACHPR 1996):The African Commission found that the conditions of detention in which children, women and the aged were held violated their physical and psychological integrity and, therefore, constituted a violation of art 5; Institute for Human Rights and Development in Africa v Angola (2008) AHRLR 43 (ACHPR 2008): The African Commission found that the state had to ensure that its immigration policies, measures and legislation did not discriminate against persons on the basis of race, colour, descent, national, ethnic origin, or any other status, and particularly take into account the vulnerability of women, children and asylum seekers; Doebbler v Sudan (2003) AHRLR 153 (ACHPR 2003) (Doebbler): I discuss this case under part 3.2.2.2 below.

55 Communication 323/2006 (2011) Egyptian Initiative for Personal Rights (EIPR) and Interights $v$ Egypt (EIPR) (2006).

56 Interights (on behalf of Pan-African Movement \& Others) $v$ Eritrea and Ethiopia (2003) AHRLR 74 (ACHPR 2003); Malawi African Association \& Others v Mauritania (2000) AHRLR 149 (ACHPR 2000) (Malawi African Association); Democratic Republic of the Congo v Burundi, Rwanda and Uganda (2004) AHRLR 19 (ACHPR 2003) (DRC); African Institute for Human Rights and Development (on behalf of Sierra Leonean refugees in Guinea) v Guinea (2004) AHRLR 57 (ACHPR 2004) (African 
aftermath of hostilities between the belligerent parties. These cases are indicative of the non-engaging approach that the Commission generally has taken towards women's rights and, more specifically, towards rape and sexual violence. Five of these cases are analysed below. ${ }^{57}$ It is possible to detect an overarching narrative, used by the Commission, to diminish the violations of women's rights. A common denominator in these cases is that there is no real attempt to detail, in any significant way, the specific abuses the women involved in these cases were subjected to, or other relevant and related issues. On the contrary, the violations are reductively interpreted, primarily with reference to 'just' rape, without any further contextualisation. In the process, the victims arguably are both disempowered and disenfranchised.

As a first example, in Malawi African Association ${ }^{58}$ the Commission was presented with a claim from, amongst others, Amnesty International, referring to the violence that had occurred in Mauritania from 1986 to 1992, between the northern Mauritanian population and the southern, black, ethnic groups. The complaint concerned violations of the rights to life, dignity, security and fair trial. ${ }^{59}$ The Northern Mauritanian population's military raided the south, detained hundreds of individuals, imposed curfews, and inflicted various forms of violence and intimidation. ${ }^{60}$ State-sponsored violence also reached the villages in the south, where security forces occupied and confiscated land and livestock, forcing the villagers to flee to neighbouring Senegal. The complaint averred that men from the southern black ethnic groups had been subjected to different forms of torture and humiliation. It is in relation to the description of the acts of massive human rights abuse taking place, as one village after another was taken over, that women are for the first time presented as

Institute); Zimbabwe Human Rights NGO Forum v Zimbabwe (2006) AHRLR 128 (ACHPR 2006) (Zimbabwe Human Rights Forum); Sudan Human Rights Organisation and Centre on Housing Rights and Evictions (COHRE) v Sudan (2009) AHRLR 153 (ACHPR 2009) (Darfur). Furthermore, a case on collective rape during military operations against the Democratic Republic of the Congo has been filed before the African Commission. IHRDA filed the case on 4 October 2016. IHRDA is awaiting confirmation of receipt from the Commission after having filed the seizure letter, http://www.ihrda.org/2016/10/case-against-the-democratic-repub lic-of-congo-before-the-african-commission-on-collective-rape-during-military-ope rations/ (accessed 28 September 2017).

57 The sixth case, Interights (on behalf of Pan-African Movement) $v$ Eritrea and Ethiopia (2003) AHRLR 74 (ACHPR 2003) was not settled by the African Commission but by a Claims Commission set up under a Peace Agreement between the governments of Ethiopia and Eritrea, signed on 12 December 2000. The agreement included a mechanism for the consideration of claims by individuals in either state whose citizenship may be in dispute. The cases of rape are referred to in para 5 of the case, where it is simply stated that 'some Ethiopian women and young girls were tortured and raped in the affected areas by Eritrean soldiers'. I have excluded the case because to the fact that it was not settled by the African Commission.

58 Malawi African Association (n 56 above).

59 Malawi African Association para 58.

60 Malawi African Association paras 18-19. 
victims of human rights violations. As described in the communication: ${ }^{61}$

Whenever the villagers protested, they were beaten and forced to flee to Senegal or simply killed. Many villagers were arrested and tortured. A common form of torture was known as the 'jaguar'. The victim's wrists are tied to his feet. He is then suspended from a bar and thus kept upside down, sometimes over a fire, and is beaten on the soles of his feet. Other methods of torture involved beating the victims, burning the victims with cigarette stubs or with a hot metal. As for the women, they were simply raped.

In this communication, the African Commission determined that the mass rape and other forms of violence violated the African Charter, in particular article 6. The Commission requested Mauritania to compensate the victims of the violations and to carry out an assessment of the 'deep-rooted causes' of the 'degrading practices' ${ }^{62}$ However, the Commission did not specify whether it considered these practices to include rape. It is clear from the quote above, and the way the Commission approached the plight of the women in this communication, that to a large extent it aimed to portray a narrative of the victimisation of African women that has dominated and still dominates the domain of international criminal law. Women, as in this case, are depicted as faceless victims of a militarised African masculinity where rape is but one of the many serious outcomes women are simply raped. There is no attempt by the Commission to detail, problematise or empower the victims to address the real root causes of the pattern of rape as presented in the case, namely, deeplyrooted misogyny.

Another comparable narrative is presented in the DRC case. ${ }^{63}$ The allegations concerned 'grave and massive violations of human and people's rights' by rebels from the three accused states against civilians living in the Congolese provinces since August $1998 .^{64}$ As part of the violence, approximately 2000 HIV positive Rwandan and Ugandan soldiers raped Congolese women and young girls in order to spread HIV to the Congolese population. The Democratic Republic of the Congo (DRC) brought the complaint asserting, among other things, that the mass rape and deliberate infection of women and girls with HIV constituted a violation of human rights under the African Charter. The respondents did not deny the occurrence of mass rape and infection, but responded that 'there is never group responsibility for violations' such as rape. ${ }^{65}$ As in the case of Malawi African Association, the rape the women were subjected to was primarily used by the African Commission to demonstrate the seriousness of the human rights violations that had occurred, but which did not merit

61 Malawi African Association para 20 (my emphasis).

62 Malawi African Association Recommendation para 5.

$63 D R C$ (n 56 above).

$64 D R C$ para 2.

65 DRC para 30. 
any further consideration. Thus, the grave violence suffered by the women subjected to the brutal rapes was diminished, as it became a simple periphrastic way of characterising the state of 'gross human rights violations' rather than to investigate the sufferings and violations of these women in more detail. Paragraph 5 of the DRC case is significant, and reads: ${ }^{66}$

The Democratic Republic of Congo also claims that the forces of Rwanda and Uganda aimed at spreading sexually transmitted diseases and committing rape. To this end, about 2000 AIDS suffering or HIV-positive Ugandan soldiers were sent to the front in the eastern province of Congo with the mission of raping girls and women so as to propagate an AIDS pandemic among the local population and, thereby, decimate it. The Democratic Republic of Congo notes that 75 per cent of the Ugandan army are suffering from AIDS. A white paper annexed to the communication enumerates many cases of rape of girls and women perpetrated by the forces of Rwanda and Uganda, particularly in South Kivu province. It further states that on Monday, 5 October 1998, in Lumunba quarter, Babozo division, Bagira commune, under the instructions of a young Rwandan officer nicknamed 'Terminator', who was then commanding the Bagira military camp, several young Congolese girls were raped by soldiers based at the said camp. Similar cases of rape have been reported from Mwenga, Walungu, Shabunda and Idjwi.

The complainants provided the white paper mentioned in the quote above to the African Commission. It details the many cases of rape of girls and women perpetrated by the armed forces of Rwanda and Uganda, particularly in the South Kivu province. In addition, Human Rights Watch (HRW) published a report on Sexual Violence Against Women and Girls in Eastern Congo in June 2002, a year before the Commission made its final decision on this communication. ${ }^{67}$ The HRW report equally provides a detailed and well-documented account of the rapes and sexual violence that occurred during this conflict. Arguably, when faced with these atrocities, the Commission could have enquired into the subjects of these atrocities and allowed them to account their experiences. The Commission could also have taken note of the HRW report, as this NGO has had a long-standing relationship with the Commission. ${ }^{68}$

None of the women's voices is brought forward in this case, again depicting rape as a pure side effect of armed conflict, as collateral damage. The obligations of state parties under, for example, the CEDAW, continue to apply during conflicts or states of emergency, without discrimination between citizens and non-citizens within their territory or effective control. ${ }^{69}$ It is, therefore, striking that even

\section{DRC para 5.}

67 Human Rights Watch 'The war within the war: Sexual violence against women and girls in Eastern Congo' June 2002 https://www.hrw.org/reports/2002/drc/ Congo0602.pdf (accessed 1 April 2017).

68 Human Rights Watch obtained observer status at the 6th ordinary session of the African Commission, 23 October-4 November 1989.

69 CEDAW General Recommendation 30 on Women in Conflict Prevention, Conflict and Post-Conflict Situations, CEDAW/C/GC/30 para 2. 
though all three respondent states had ratified the CEDAW ${ }^{70}$ at the time these atrocities were committed, the Commission made no attempt to use its mandate under article 60 to make reference to this treaty.

In a later case, African Institute, ${ }^{71}$ rape was discussed in a little more detail. In a radio broadcast in September 2000, the President of Guinea called on citizens and the armed forces of Guinea to engage in mass discrimination against Sierra Leonean refugees in Guinea. The speech motivated civilians to rise up against the refugees, resulting in what the African Commission refers to as 'rapes and shootings'. ${ }^{72}$ In paragraph 41 of the communication, the Commission details the applicable international and regional human rights law in accordance with article 60 of the African Charter. The Commission refers to the Charter; the OAU Convention on Specific Aspects of Refugee Problems in Africa; the International Convention on Civil and Political Rights (ICCPR); the Convention on Torture and Other Cruel, Inhuman or Degrading Treatment or Punishment (CAT); and the 1951 UN Refugee Convention and its Protocol. Importantly, Guinea ratified the CEDAW in 1982, but again no attempt was made to apply this treaty to the violence experienced by women. According to the complaint, Sierra Leonean women were raped as a way to 'punish them for being so-called rebels'. ${ }^{73}$ The soldiers and civilians used weapons to intimidate and threaten the women, and women of various ages were raped in their homes, in various prisons, and in refugee camps. ${ }^{74}$

While the African Commission clearly had the opportunity and the legal instruments, such as the CEDAW, at its disposal to go beyond the purely reductive narrative in DRC and African Institute, it did not do so. Instead, it remained trapped in what can be referred to as its 'women as victims of rape' discourse. This discourse not only diminishes the transformative potential of human rights instruments such as the African Charter and the CEDAW, but also reproduces gender stereotypes present in colonial discourse. Women's sexual security, in these cases, seems to function only as a yardstick of civilisation, that is, that 'these individuals are not civilised and thus they will rape and be raped'. This narrative then is placed in a context where the African continent is reduced to a position of ongoing civil unrest and war.

In Zimbabwe Human Rights Forum ${ }^{75}$ the African Commission was once again confronted with cases of sexual violence and rape. As violence erupted in Zimbabwe between the constitutional referendum of 2000 and the parliamentary elections later that year, supporters of

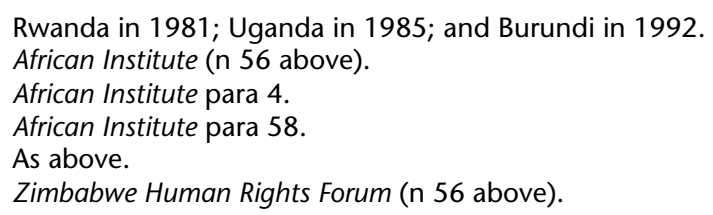


ZANU (PF) engaged in various human rights violations. The outcome of this case has significance as the Commission determined that '[a] state can be held complicit where it fails systematically to provide protection of violations from private actors who deprive any person of his/her human rights'.76 However, the Commission once again permeated an undetailed and unengaged version of women's suffering by simply referring to the fact that 'women and children were tortured and there were cases of rape' ${ }^{77}$ Clearly this does not only silence the women involved but also curtails their agency as, for example, prominent political activists. Again, it is important to acknowledge that Zimbabwe had, already in 1991, ratified the CEDAW, yet the Commission made no attempt to discuss either the sexual violence or rape under this instrument. It should also be added that at the time the violations in the DRC, African Institute and Zimbabwe Human Rights Forum cases took place, the CEDAW Committee had presented General Recommendation 19 on violence against women, specifically defining gender-based violence as a form of discrimination.

To reverse the risks of presenting a single, undetailed tale of rape, as portrayed in the cases above, diverse contextualised accounts of rape and sexual violence should be included. Significantly, the women, as subjects of these experiences, should be offered the opportunity to relate their experiences. ${ }^{78}$ It might not be possible to hear or gather evidence from all parties involved, but at least the African Commission, with its very relaxed attitude towards the victim requirement in article 56 of the African Charter, could solicit further evidence and invite other narratives to perform its mandate to promote, protect, respect and fulfil all human rights. Another case assessed by the Commission, that of Darfur, ${ }^{79}$ demonstrates the importance of this point, illustrating how the inclusion of women's voices can disrupt the 'women as victims of rape' discourse.

In 2003, an armed group known as the Sudan Liberation Army issued a political declaration and later clashed with Sudanese armed forces. During the drawn-out conflict in the Darfur region, Sudan, the respondent state, engaged in a succession of human rights violations against suspected insurgents, including the rape of women and girls. The African Commission noted that 'cases of sexual and gender-based violence against women and girls in and outside IDP camps ha[d] been a common feature of the Darfur conflict' ${ }^{80}$ Considering the grave nature of the conflict, the Commission sent a Special Mission to

Zimbabwe Human Rights Forum para 160.

Zimbabwe Human Rights Forum para 4 (my emphasis).

78 Report of the African Commission's fact-finding mission to the Republic of Sudan in the Darfur region, 8-18 July 2004, EX.CL/364 (XI) Annex III paras 11 \& 46-95.

79 Darfur (n 56 above).

80 Darfur para 178. 
the Darfur region to report on the conflict. ${ }^{81}$ Whereas the African Commission's analysis of the case does not differ much from the cases discussed above, the personal experiences related by refugee women to the Commission clearly had a disruptive effect on the 'victim' narrative. It is important to acknowledge that information surrounding the cases of rape assists the critical interrogation of rape and further highlights the complexity of the victims' situation. The Commission's Special Mission involved interviewing some female internally-displaced persons (IDPs), who reported as follows: ${ }^{82}$

[T] heir villages were attacked by government forces, supported by men riding horses and camels. The attacks resulted in several deaths and injury of people. Some of these women who sustained injuries, showed their wounds to the Commission. The women furthermore stated that during the attacks, a number of cases of rape were committed, some of the raped women became pregnant. Complaints were lodged at the police but were yet to be investigated. They declared that the attackers came back at night to intimidate the villagers who had not fled, accusing them of supporting the opposition. Everyone had to run away from the villages. The women indicated that they were traumatised by the violent nature of the attacks and said that they would not want to return to the villages as long as their security is not assured. They lamented lack of water and a school in the camp. The mission visited the police station to verify complaints and the level of progress made on the reported cases of rape and other offences, but the mission was unable to have access to the files as the officer in charge of the said cases was absent at the time. At one of its meetings in El Geneina, the mission was informed by the authorities of West Darfur State that even though cases of rapes [rape] were reported to the police, investigations could not be conducted because the victims could not identify their attackers. Therefore the files were closed for lack of identification of the perpetrators.

For these victims, the act of rape unquestionably was an important part of the violations they endured. However, as acknowledged in their statements, the surrounding circumstances, such as the inability to report their cases to the police, the resulting pregnancies, their inability to access water and the impossibility of sending their children to school, were also made visible in their personal accounts. Their enduring sense of insecurity was not only based on the threat of sexual violence, but also on other forms of intimidation, including the fear of being evicted from their homes. In fact, in the women's narratives there was a clear link between the evictions and rape. These narratives describe other, otherwise unknown, dimensions of the lives of these women; arguably, equally important but hidden in the 'women as victims of rape' discourse. The introduction of women's voices and perspectives stands in stark contrast to the female subject constructed by the African Commission in DRC, African Institute and Zimbabwe Human Rights Forum. In Darfur, for the first time in the

81 The African Commission conducted a fact-finding mission to the Darfur region of Sudan between 8 and 18 July 2004. The Commission adopted the report of the mission during the 3rd extraordinary session, held in Pretoria, South Africa, 8-19 September 2004.

82 Darfur (n 56 above) para 151. 
jurisprudence of the Commission, one actually sees women thinking and speaking for themselves.

\section{Women's rights under the human dignity clause in the African Charter}

As mentioned above, three of the cases relating to women's rights are classified under the right to dignity clause in the African Charter. In Doebbler, ${ }^{83}$ eight female students were arrested for allegedly having engaged in immoral activities that violated Sudan's Criminal Code which incorporates Shari'a law. The immoral activities the women were accused of committing consisted of 'girls kissing, wearing trousers, dancing with men, crossing legs with men, sitting with boys, and sitting and talking with boys' ${ }^{84}$ The women were punished with fines and between 25 and 40 lashes each. ${ }^{85}$ The lashing took place in public, by use of a wire and plastic whip. ${ }^{86}$ The women were bareback while they were being lashed. ${ }^{87}$ The complaint asserted that the punishment violated article 5 of the African Charter, which guarantees the right of individuals to human dignity and prohibits cruel, inhuman or degrading punishment and treatment. The African Commission found that the lashing violated article 5 of the African Charter and requested Sudan to abolish the punishment of lashing and to compensate the women for their injuries.

The importance of this case does not hinge on the findings of the African Commission as such, but rather on the obvious issues that were not discussed, and the statements it made on Shari'a law. As Sudan has not ratified the CEDAW, the Commission had to rely squarely on the African Charter. Some reflections again placed the spotlight on the Commission's non-engagement with women's rights. First, it is questionable why the Commission did not treat this as a case of discrimination, as the boys involved were not arrested or punished. Second, the Commission accepted the fact that the crimes, as they were stipulated in the Sudanese Criminal Code, had been undisputed by the parties, yet the Commission did nothing to engage with or interrogate its discriminatory nature. Third, even though the complainants referred to the argument that, in accordance with Shari'a law, lashing may only be meted out in the case of serious crimes, not the type of acts committed by the girls, the Commission took the position that 'it was not invited to interpret Islamic Shari'a law as obtained in the Criminal Code of the respondent state' ${ }^{88}$ In an attempt to escape the 'relativism' debate, the Commission limited the inquiry to the application of the African Charter in the legal system of Sudan as a party to the Charter without reflecting on the influence of

83 Doebbler (n 54 above).

84 Doebbler para 3.

85 Doebbler para 30.

86 As above.

87 As above.

88 Doebbler para 41. 
Shari'a law. By only engaging with the cruel and inhuman punishment aspect of this case under article 5, the Commission arguably lost an important opportunity to discuss the combined effect of articles 1, 2, 3 and 18(3) of the African Charter. Even without directly discussing Shari'a law, the Commission arguably could have brought forward important questions about the discriminatory nature of the crimes, the arrest and subsequent punishment as well as women's overall subjugated position in Sudanese society.

Obligation to protect women from sexual violence under article 18(3) of the African Charter

So far, the case of Egyptian Initiative for Personal Rights $(E I P R)^{89}$ represents the African Commission's only direct engagement with women's rights. The complaint was filed in 2006, but the decision was only finalised in December 2011. The Commission mentions the African Women's Protocol in this case, but as Egypt has not ratified the Protocol, it could not be directly applied.

The backdrop to EIPR is a demonstration organised by the Egyptian Movement for Change (Kefaya) in May 2005 in respect of the referendum aimed at amending the Egyptian Constitution. During these demonstrations, four female journalists were sexually assaulted, beaten and intimidated. The victims claimed that these violations occurred in the presence of high-ranking officers of the Egyptian Ministry of Interior and the riot police. ${ }^{90}$

EIPR presented the African Commission with a critical opportunity to confirm, in line with the decisions of the CEDAW Committee, that violence against women can amount to discrimination under the African Charter, according to articles 1, 2 and 18(3). The applicants argued that the state has a positive obligation to prevent private individuals from harming the victims (due diligence) and to investigate whether such violations had taken place; that they were discriminated against under articles 2 and 3, with regard to their sex and political opinion; and that violence of this nature against women should be recognised as a violation of article 18(3). ${ }^{91}$ As far as the latter is concerned, the applicants averred that 'the sexual abuse endured by the [v]ictims [was] gender specific and amount[ed] to discrimination on the grounds of sex, which is a violation of [a]rticle 18(3) of the African Charter'.92 The applicants furthermore referred the Commission to article 1 of the African Women's Protocol, arguing that 'it strongly underscores violence against women, whether it is physical, sexual or psychological'. 93

\footnotetext{
$89 \operatorname{EIPR}$ (n 55 above).

90 EIPR para 3.

91 EIPR paras 69-74.

92 EIPR para 90.

93 EIPR para 87.
} 
In its analysis, the African Commission explored the definition of discrimination and the relationship between discrimination and gender-based violence. ${ }^{94}$ In this regard, it is important to note that Egypt had ratified the CEDAW in 1981, albeit with reservations, ${ }^{95}$ but had not ratified the African Women's Protocol. However, the Commission nevertheless referred to article 1(f) of the African Women's Protocol in defining discrimination against women, further referring to article 1 of the CEDAW as well as General Recommendation 19 in establishing the correlation between discrimination against women and gender-based violence. ${ }^{96}$ To establish the alleged violation of article 2, the Commission analysed the witness statements of the four victims. The respondent claimed that no discrimination had taken place, as the assaults had not been inflicted on the victims because of them being women. The state maintained that both men and women participated in the protest. The Commission drew the following important conclusions from the assaults as described in the affidavits of the four victims, namely, (i) that all victims were women; (ii) that they were not protected against the abuse by the perpetrators and other unidentified actors during the demonstration; and (iii) that the violations were perpetrated on these victims because of their gender. ${ }^{97}$ Thus, men and women had not been treated similarly during the demonstration and, as such, the respondent had violated article 2 of the African Charter.

The second leg of the analysis, whether the assaults amounted to discrimination, took place under the ambit of article 18(3). The applicants submitted that the sexual abuse they had endured were 'gender-specific, amounting to discrimination on the grounds of sex'. ${ }^{98}$ The applicants further averred that the respondent had failed to protect the victims from said discrimination by not taking any measures to comprehensively investigate, prosecute and punish the perpetrators. In this regard, the African Commission commented that 'the characteristics of violence commonly committed against women and men differ, and it is only by analysing the nature of the violence that the Commission can effectively draw its conclusions' ${ }^{99}$ The Commission highlighted three different aspects of the assaults. First, the verbal assaults, namely, using gender-specific language by calling the victims 'sluts' and 'whores', in the opinion of the Commission,

94 EIPR para 120.

95 General Reservation on art 2: 'The Arab Republic of Egypt is willing to comply with the content of this article, provided that such compliance does not run counter to the Islamic Shari'a; and specific reservations to arts 16 and 29. On 4 January 2008, the Egyptian government notified the Secretary-General that it had decided to withdraw the reservation to art 9(2) made upon ratification. 
were used to humiliate the women as punishment for refusing to abide by the traditional religious norms set by Egyptian society. ${ }^{100}$ Second, the assaults as such were gender specific as they targeted the breasts and private parts of the victims. The victims' clothes were torn or removed in an attempt to humiliate them. Some of the victims furthermore were threatened with allegations of prostitution if they refused to withdraw their allegations. ${ }^{101}$

Not every differentiation will constitute discrimination. ${ }^{102}$ If the differentiation is deemed reasonable and objective with the aim of achieving a legitimate purpose under the applicable human rights instrument, it should not be deemed discriminatory. However, in this case the African Commission found that the violence was gender specific and, thus, discriminatory by extension and, as the respondent had neither protected the victims from the violations nor put forward any evidence to suggest that the differentiation was legitimate, it was deemed a violation of article 18(3). ${ }^{103}$ The Commission furthermore concluded that state actors, as well as non-state actors under the control of state actors, had perpetrated the acts of gender-based violence, and that such acts went unpunished. ${ }^{104}$ The acts were designed to silence them and to deter any further activism. ${ }^{105}$

Furthermore, referring to Zimbabwe Human Rights Forum, the African Commission stipulated that equality before the law meant that 'existing laws must be applied in the same manner to those subject to them'. ${ }^{106}$ The Commission asserted that equality before the law necessitated equality in the administration of justice. The Commission found that the respondent state had violated article 3 since freedom from discrimination was also an aspect of the principles of equality before the law and equal protection of the law, as both present a legal and material status of equality and non-discrimination.

\section{Conclusion}

Concerned with viewing the rule of law through a feminist lens, this article set out to explore the effects of the absence of a committee on the rights of women in Africa, on women's access to the regional justice system and the enforcement of the African Women's Protocol.

Aiming to analyse this issue from a structural perspective, on the level of the AU human rights framework, the article departed from two assumptions: first, that using the mainstream human rights institutions such as the African Commission and the African Court

100 EIPR para 143.

101 EIPR para 145

102 EIPR para 146.

103 EIPR para 153.

104 EIPR para 166.

105 EIPR para 166.

106 Zimbabwe Human Rights Forum (n 56 above) para 96. 
would present a number of challenges to the implementation of women's rights; and, second, that a specialised women's rights institution would serve two important purposes, namely, as a receiver of litigation and as a driver of implementation.

As is evident from the discussion in the article, the challenges of mandating the African Commission and Court with protecting and promoting women's rights without considering the existing structures, biases and priorities are real. These present (i) the structural hurdles built into the African Court Protocol preventing direct access for most individuals and NGOs, thereby making the African Commission the main body for handling women's claims; (ii) the conflation of the reporting mechanisms, subsequently limiting the reach and value of the reports; (iii) the 'simply raped' narrative, thereby producing a voiceless female subject who is acknowledged only by alluding to her sexuality and, thus, her vulnerability to rape; (iv) the lost opportunities to apply the CEDAW when possible, thwarting important arguments of non-discrimination; and ( $v$ ) the non-engaged approach to women's rights evident in the jurisprudence of the African Commission, creating minimal incentives for women and NGOs to address their complaints to the Commission.

In terms of the effects of the optional jurisdiction declaration and the slow ratification of the African Court Protocol, it is clear that the original idea, albeit naive (considering the optional jurisdiction clause), of giving the African Court the main mandate to monitor the enforcement of the African Women's Protocol, has been severely hampered. In an ideal world, where state parties readily accept the jurisdiction of international bodies, such as the African Court, the African Women's Protocol arguably would prescribe a stronger monitoring mechanism than, for example, the African Children's Charter. As far as the latter is concerned, claims of violations can be presented to the African Children's Committee, which at present does not have locus standi before the African Court. ${ }^{107}$ However, when the following facts and assumptions are considered together, it becomes clear that the current model has little to offer in terms of enforcing women's rights: (i) the fact that the African Commission does not have much jurisprudence in the way of women's rights to show for almost 12 years after the inception of the African Women's Protocol (except in the case of EIPR); (ii) the fact that the Commission has not shown much willingness to refer cases to the African Court (three to date); (iii) the assumption that other bodies (states and African intergovernmental organisations) that have access to the Court will not bring women's rights cases to the Court in any significant way as it is not in their interests (to date none has been received); and (iv) the very slow process of optional jurisdiction declarations (eight to date).

107 ACRWC advisory opinion (n 42 above). 
Since litigation against the optional jurisdiction clause has proven fruitless to improve women's access, ${ }^{108}$ the African Commission would have to either re-conceptualise its approach to women's rights along with its willingness to bring cases before the African Court, or the structure would have to be reconsidered altogether. In terms of the latter, provided the relevant funding is afforded, an appropriate model could be to use the same structure for the enforcement of the African Women's Protocol as is constructed in the African Children's Charter, that is, a specialised body serving as a first instance with the opportunity to refer cases to the Court. ${ }^{109}$ As indicated above, the African Children's Committee currently does not have locus standi under the African Court Protocol. However, this has been rectified in the Protocol on the Statute of the African Court of Justice and Human Rights (Merger Protocol) presenting a two-tier, specialised mechanism based on complementarity. ${ }^{110}$ As addressed by the African Court in the ACRWC Advisory Opinion, the apparent anomaly, that the African Children's Committee was not given the same position as the African Commission, was later addressed in the Merger Protocol. ${ }^{111}$ The omission of a committee on the rights of women in Africa, under the African Women's Protocol, could be rectified under the amendment clause in articles 30 of the Women's Protocol and, instead of this, article 35 of the Women's Protocol and articles 58 and 59 of the Merger Protocol could be used to create appropriate locus standi for such a committee. The fact that the African Women's Protocol is adjacent to the African Charter does not summarily prevent it from establishing a structure complementary to the African Commission, the African Children's Committee and the African Court, as article 66 of the African Charter merely stipulates that '[s]pecial protocols or agreements may, if necessary, supplement the provisions of the present Charter'. Establishing a committee on the rights of women in Africa arguably would supplement the rights in the African Charter, and would strengthen the protection of these rights as elaborated on in the African Women's Protocol. There are always issues in defining complementarity and avoiding an overlap in a complex structure such as this. ${ }^{112}$ However, a specialised institution with equal powers, modelled on the CEDAW Committee, would honour women's rights

108 App 001/2011, Femi Falana v African Union, African Court on Human and Peoples' Rights and App 014/2011, Atabong Denis Atemnkeng $v$ African Union, African Court on Human and Peoples' Rights.

109 It is prudent to note that the African Children's Committee does not contain a clause specifying where its funds should be sourced, equal to art 41 of the African Charter and art 32 of the Protocol clarifying that in terms of the Commission and the Court, this is the responsibility of the AU, that is, the Assembly of Heads of State and Government.

110 Art 30(c), providing the African Children's Committee locus standi before the African Court of Justice and Human Rights.

111 ACRWC advisory opinion (n 42 above) para 93.

112 See A Rudman 'The Commission as a party before the Court: Reflections on the complementarity arrangement' (2016) 19 Potchefstroom Electronic Law Journal 1-29. 
to equality and non-discrimination in the same manner as the African Children's Committee honours the best interests of the child, arguably all important aspects of the rule of law. As the AU currently places much emphasis on women's rights, it would be prudent to not only continue to urge states to make good on the promises in the AU gender policy, to achieve full ratification and enforcement of the African Women's Protocol, but to also combine this with an effective enforcement structure ultimately strengthening the rule of law for all. 